\title{
SATELLITE TRACKING AND RECOVERY OF A MARBLED GODWIT AT THE LAST MOUNTAIN LAKE NATIONAL WILDLIFE AREA, MAY- SEPTEMBER 2006
}

ROSS D. DICKSON, Last Mountain Lake National Wildlife Area, Box 280, Simpson, SK, SOG 4M0, E-mail: <rossdickson@sasktel.net>; and PHILIP S. TAYLOR, Canadian Wildlife Service, 115 Perimeter Road, Saskatoon, SK, S7N OX4

Last Mountain Lake National Wildlife Area (LML NWA) is recognized for its importance to migrating shorebirds through its designation as a wetland of international importance (RAMSAR) and as a member of the Western Hemisphere Shorebird Reserve Network. In 2006, one migrating shorebird demonstrated the importance of the continental wetland network.

In April, 2006 an adult female Marbled Godwit (hereafter, godwit)

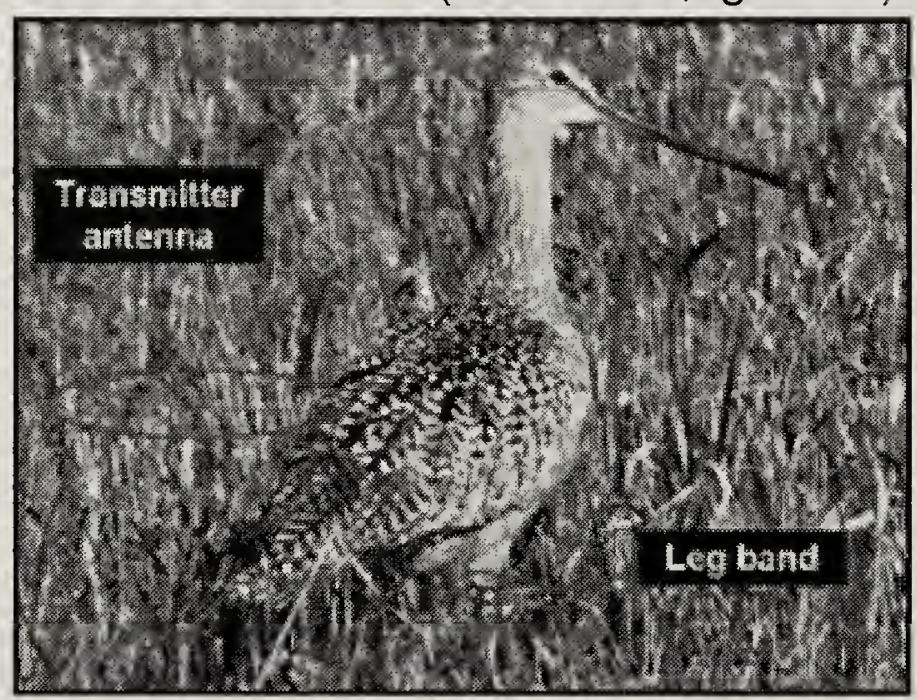

Figure 1. Female marbled godwit outfitted with transmitter and plastic leg bands in Utah. An aluminum numbered band on the upper left leg cannot be seen in this photo, taken on 4 May 2006.

Philip S. Taylor was trapped and outfitted with coloured leg bands and a solarpowered satellite transmitter (12 g) at the Bear River Migratory Bird Refuge (BRMBR) in Utah (Fig. 1) by the U.S. Geological Survey (USGS) and the U.S. Fish and Wildlife Service (USFWS). Continuous recording of movements by the bird was conducted for a 6 -hour period out of every 30 hours.

The godwit remained at the BRMBR until 30 April 2006 (Fig. 2). At 1030h, the satellite signal indicated that the bird was probably in flight about $70 \mathrm{~km}$ north of the BRMBR. The next signal came from Old Wives Lake Migratory Bird Sanctuary in southern Saskatchewan on 1 May, indicating that the bird had moved in a direct flight of approximately $1100 \mathrm{~km}$. Exact arrival time is unknown because of the satellite blackout period. The following day, the signal came from the northeast corner of the LML NWA, approximately $150 \mathrm{~km}$ farther northeast.

The godwit was found and photographed in a hayfield in the LML NWA on 4 May with a second godwit. The presence of a second adult, which 


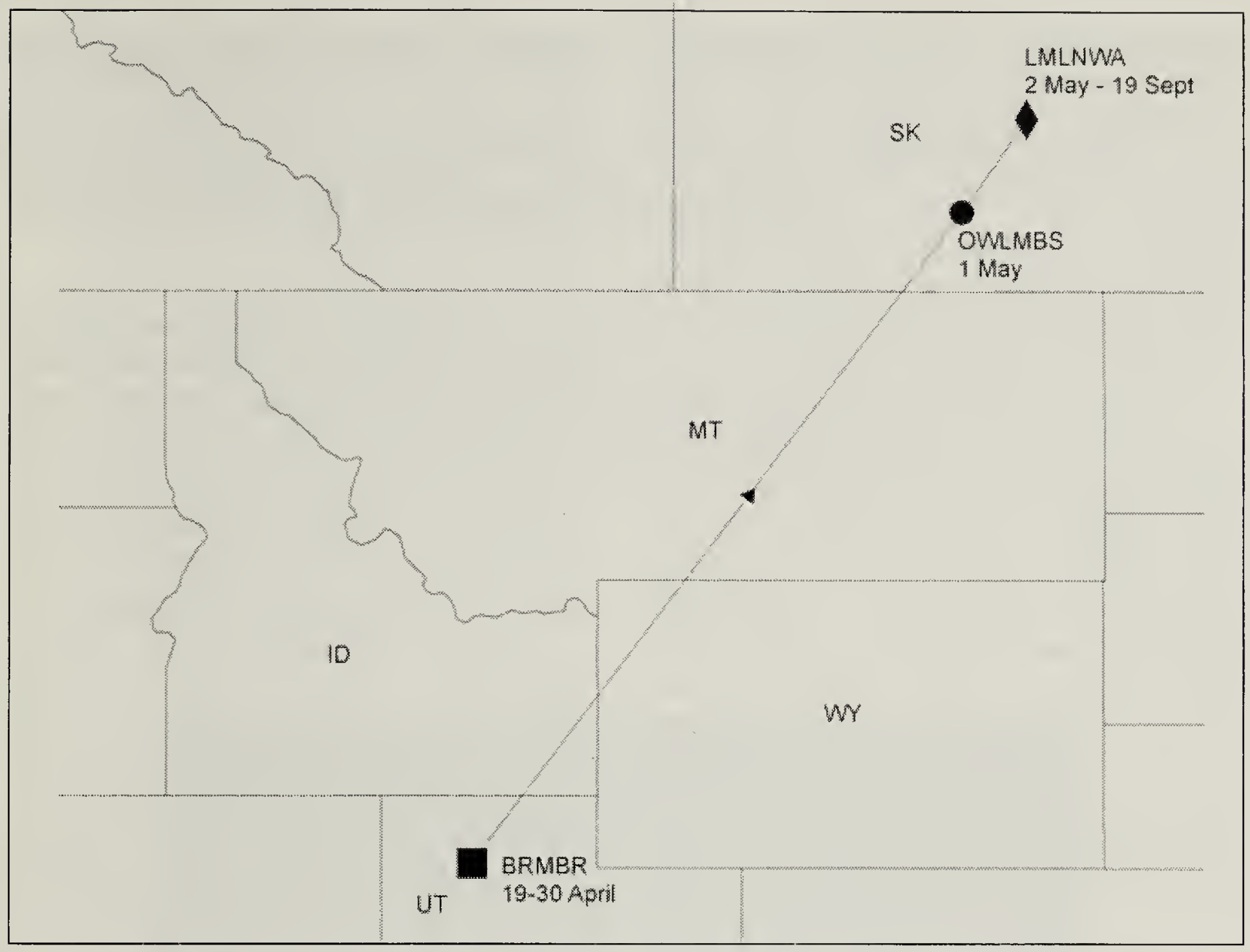

Figure 2. Migration route of a Marbled Godwit between Bear River Migratory Bird Refuge (BRMBR; Utah), Old Wives Lake Migratory Bird Sanctuary (OWLMBS; Saskatchewan) and Last Mountain Lake National Wildlife Area (LML NWA; Saskatchewan), 30 April to 2 May 2006.

Lois Vanthuyne

was observed chasing other godwits in the immediate area during the same morning, suggested that a territory was being established. The godwit was nicknamed "Sassy" because she had flown to Saskatchewan.

"Sassy" was monitored by satellite throughout the summer. Concern was raised in late August, as transmitter signals continued to come from the same area where "Sassy" spent the summer. Many adult female godwits leave their breeding areas in Saskatchewan to join post-breeding flocks by early July, although a few will remain until chicks fledge. The USFWS contacted us and requested a search be made to locate the radio transmitter and to determine the fate of the bird if possible. The satellite signal indicated some movement; however, signal drift likely accounted for this (the transmitter's accuracy was $\sim 125 \mathrm{~m}$ ).

We conducted a series of gridpatterned walking searches in the area from which the signal came but failed to find any clues about either the godwit or the transmitter. A metal detector was ineffective because tall grass prevented it from getting close enough to the ground. Eventually, a weed trimmer was used to remove visual obstruction by vegetation stems. The colour of the transmitter was a dull khaki green, making detection more difficult.

Much of the search area was covered with tall, thick stands of Smooth Brome Grass (Bromus inermus), Canada thistle (Cirsium 
arvense), and Western Snowberry (Symphoricarpos occidentalis). This vegetation structure seemed unsuitable as a feeding, nesting, or roosting area when more typical godwit habitat of short patchy vegetation at a newly-dried shallow slough was nearby.

After more than 7 hours (over 2 days) of weed trimming, the remains of a godwit skeleton were found near an LML NWA boundary fence on 19 September (Fig. 3). The upper skeleton was intact, completely stripped of all flesh, but the leg bones were missing, and there was no transmitter. It took another 3 hours to find the leg bones, the coloured leg bands, and the transmitter, which were lying together about $10 \mathrm{~m}$ farther along the fence.

The cause or date of the death is unknown. The drift of the satellite signal suggested movement even after the bird was dead. Possible predators include Swainson's Hawks (a nest was active $\sim 100 \mathrm{~m}$ from the recovery site) or coyote; however, remains of the body do not strongly suggest either predator. Avian predators usually pluck bird prey but often decapitate the body in the process of eating the flesh. A coyote would have dismembered the body. The skull was still attached to the spine when found. A few primary flight feathers were also recovered from beneath the skeleton.

For decades, biologists have relied heavily on the recovery of banded birds to determine migration patterns. The recovery rate for most species is very low. Even when a band is found, many questions remain unanswered, including speed of migration, exact dates of movements, and locations of important stopover points where "refuelling" takes place. This experiment with satellite technology answered some of these questions about Marbled Godwit migration to Saskatchewan. "Sassy" linked three of the 64 sites designated as crucial for shorebirds in the Western Hemisphere.

\section{Acknowledgements}

We thank the Blue Jay editors and an anonymous reviewer for their suggestions to improve the manuscript. Adrian Farmer (USGS) and Bridget Olson (USFWS) trapped and outfitted the godwit. Lois Vanthuyne (Canadian Wildlife Service) prepared the map.

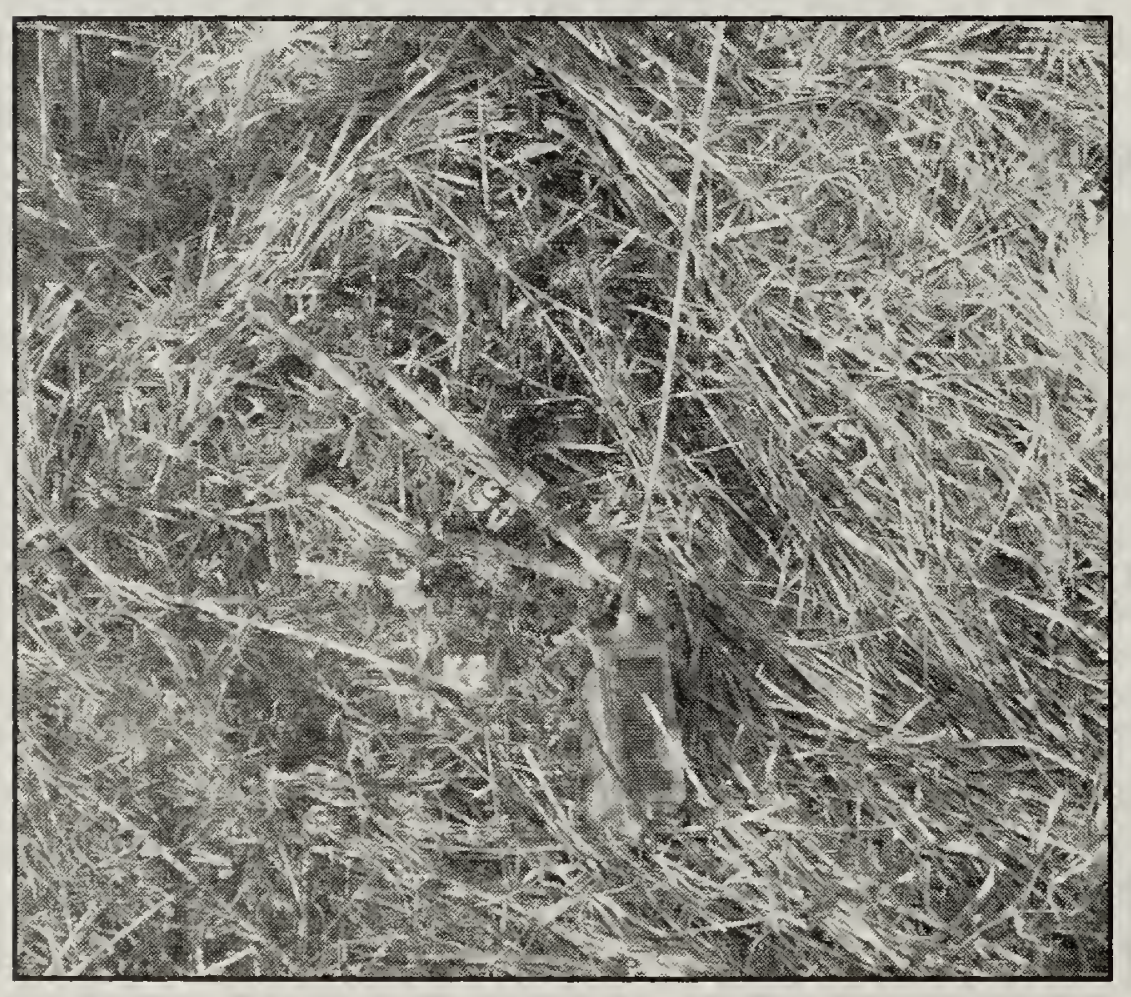

Figure 3. Coloured leg bands, leg bones, and satellite transmitter at the recovery site after a covering of dead grass had been removed from above the items to help their visibility for this photograph 19 September 2006.

Ross Dickson 